\title{
NEW SITES OF RARE COLD-WATER GOLDEN ALGAE HYDRURUS FOETIDUS (VILLARS) TREVISAN (OCHROPHYTA: CHRYSOPHYCEAE) IN CROATIA
}

\section{Nikola Koletić, Antun Alegro*, Vedran Šegota, Nina Vuković, Anja Rimac \& Tihana Vilović}

University of Zagreb, Faculty of Science, Division of Biology, Department of Botany, Marulićev trg 20/II, 10000 Zagreb, Croatia

Koletić, N., Alegro, A., Šegota, V., Vuković, N., Rimac, A. \& Vilović, T.: New sites of rare coldwater golden algae Hydrurus foetidus (Villars) Trevisan (Ochrophyta: Chrysophyceae) in Croatia. Nat. Croat., Vol. 26, No. 2, 305-311, 2017, Zagreb.

Two new sites with benthic freshwater alga Hydrurus foetidus (Villars) Trevisan have been discovered in Dinaric Ecoregion of Croatia. The sites are located in two karst watercourses: Kupa River and Slušnica River. Both sites are non-shadowed aquatic habitats, with developed vegetation characteristic for clear, running waters. The alga was found during summer months at its disintegration stage, and during autumn at the beginning of its growing stage. In the Kupa River, incrusted calcium carbonate was found within the thalli of $H$. foetidus. After the first known record in Bijela Rijeka River from 2015, our findings represent the second and the third known localities of this species in Croatia. Even though the vegetation composition indicates high ecological status of the sites, future anthropogenic impacts and climatic changes could become a threat to this underexplored species in Croatia.

Keywords: benthic, freshwater, macroalgae, Slušnica River, Kupa River

Koletić, N., Alegro, A., Šegota, V., Vuković, N., Rimac, A. \& Vilović, T.: Novi nalazi rijetke hladnovodne zlatnožute alge Hydrurus foetidus (Villars) Trevisan (Ochrophyta: Chrysophyceae) u Hrvatskoj. Nat. Croat., Vol. 26, No. 2, 305-311, 2017, Zagreb.

Dva nova nalaza bentičke slatkovodne alge Hydrurus foetidus (Villars) Trevisan zabilježena su u dinarskoj ekoregiji u Hrvatskoj. Nalazi su locirani u dva krška vodotoka: rijeka Kupa i Slušnica. Na oba istražena nalazišta alga raste na nezasjenjenim staništima s vodenom vegetacijom makrofita karakterističnom za čiste tekuće vode. Alga je uočena tijekom ljeta u fazi raspadanja talusa te tijekom jeseni u početnoj fazi rasta. Na talusu jedinki iz rijeke Kupe primijećen je inkrustat kalcijevog karbonata. Nakon nalaza u Bijeloj rijeci 2015. godine, ovi nalazi predstavljaju drugi i treći nalaz ove rijetke vrste u Hrvatskoj. Iako sastav vegetacije ukazuje na vrlo dobro ekološko stanje na oba nalazišta, mogući antropogeni pritisci i klimatske promjene u budućnosti mogli bi ugroziti ovu nedovoljno istraženu vrstu u Hrvatskoj.

Ključne riječi: bentos, slatkovodna, makroalga, rijeka Slušnica, rijeka Kupa

\section{INTRODUCTION}

Hydrurus foetidus (Villars) Trevisan is a large (10-30 cm), branched, benthic freshwater golden algae (Ochrophyta: Chrysophyceae), distributed worldwide (WeHr \& Sheath, 2003), but restricted to cold mountain streams in early spring and lowland rivers at latitudes with cold, homogeneous climatic conditions (Klaveness et al., 2011; Klaveness, 2017). In climates with defined seasons, the algae is

* corresponding author 
mainly found in cold conditions; in springtime during snowmelt when daylight starts to increase, during summer/autumn in rivers flowing along glacial landscapes (WARD, 1994; RotT et al., 2006a) or in the cold running waters in the mountains (CANTONATi et al., 2006). Hydrurus foetidus is easily recognizable at the time of emerging bloom from March to April, due to its brown colour and the gelatinous thalli. However, as the temperatures increase, competing green algae start to dominate and can easily occupy the watercourse bed, therefore $H$. foetidus can be difficult to detect during summer months (RoTT et al., 2006b).

The optimal temperature for its growth is between 2 and $12^{\circ} \mathrm{C}$ (KAWECKA, 1981); when the water temperature rises to $16^{\circ} \mathrm{C}$ the thalli begin to fragment and disappear (Bursa, 1934; KANN, 1978). It was previously reported that $H$. foetidus forms numerous conglomerations in open habitats, while its abundance drastically decreases in the shade (KAwECKA, 2003); however, some authors reported its occurrence even under ice (Souires et al., 1973).

According to Guiry (2017) and KLaveness (2017), H. foetidus is mostly widespread in the northern hemisphere, with a large number of records in Europe, especially Austria, France, Great Britain, Italy, Norway, Poland, Russia, Switzerland, Spain, Sweden and Turkey. In Croatia, H. foetidus was firstly recorded in 2015 on a single site in the Bijela Rijeka River in the Plitvice Lakes National Park (Stanković \& LeITNER, 2016). In spite of many known sites of this species in Europe, descriptions of its adaptations to different habitats and ecological conditions are still mostly missing. Therefore, these records are filling the gaps in knowledge and confirming it as coldwater habitant in mountainous rivers of Dinaric karst as well.

\section{MATERIAL AND METHODS}

\section{Study area}

Field work was performed on August $3^{\text {rd }} 2016$ and November $23^{\text {rd }} 2017$ in the spring area and upper course of the Kupa River (N 45.504959, E 14.700611), near village Kupari, and on July $20^{\text {th }} 2017$ in the spring area of the Slušnica River (N 45.07963, E 15.58955). Both rivers are karst mountainous watercourses, belonging to the Black Sea watershed, situated in the Continental Subecoregion of the Dinaric Ecoregion of Croatia (Hrvatske Vode, 2015). Also, they are a part of the NATURA 2000 ecological network (National Gazette, 124/2013, 105/2015). According to the biotic type, both rivers belong to the category HR-R-7 - mountainous and hilly medium and large watercourses (NATIONAL GAZETTE, 73/2013, 151/2014, 78/2015).

The karst limnocrenic spring of the Kupa River is situated in the Risnjak National Park in the mountainous area of Gorski Kotar, on $374 \mathrm{~m}$ a.s.1. In the upper flow, the Kupa River runs fast through the narrow forest canyon, slowing down after a few kilometres.

The Slušnica River is the left tributary of the Korana River, about 6 km long (Hrvatska AgenciJA ZA OKOLIš I Prirodu, 2015). Its abundant karst spring is situated on $270 \mathrm{~m}$ a.s.l. in the hilly area of Lika. It starts as a small lake in the central part of the natural amphitheatre, followed by the artificial dam, canyon and rich travertine waterfalls.

\section{Sampling and analysis of algae and macrophyte vegetation}

The algal material was collected from riverbeds of both rivers. Live material was identified according to WeHr et al. (2015) and STARMACH (1985), photographed and transported to the laboratory. For microscopic analysis 15-650× magnification was used. Additional material was collected for preservation with $4 \%$ formaldehyde and desiccation with silicagel. The collected material was deposited in herbarium ZA (Thiers, 2016). A vegetation survey was performed along $50 \mathrm{~m}$ of the watercourse. Species coverage and abundance were assessed using the expanded Braun-Blanquet's scale (BRAUNBlanquet. 1964; Barkman et al., 1964; DierschKe, 1994), where category 2 was subdivided into $2 m, 2 a$ and $2 b$. The nomenclature follows EURO+MED PLANTBASE (2017).

\section{RESULTS AND DISCUSSION}

We have found $H$. foetidus on two sites, characterized by mesolithal and megalithal substrata and abundant aquatic vegetation typical for spring areas. The physical and chemical properties of water (Tab. 1) were recorded monthly by the State Institution for Water Management "Hrvatske vode" in 2013. 
Tab. 1. Physical and chemical properties of water on the localities of H. foetidus in 2013 based on monthly measurements (Data source: Hrvatske vode).

\begin{tabular}{|l|c|c|c|c|}
\hline & \multicolumn{2}{|c|}{ Kupa River } & \multicolumn{2}{c|}{ Slušnica River } \\
\hline Parameter & Range & Mean & Range & Mean \\
\hline Temperature $\left({ }^{\circ} \mathrm{C}\right)$ & $2.0-12.0$ & 7.6 & $2.9-15.8$ & 10.9 \\
\hline $\mathrm{pH}$ & $8.0-8.3$ & 8.2 & $7.8-8.0$ & 8.0 \\
\hline Electrical conductivity $(\mu \mathrm{S} / \mathrm{cm})$ & $239-283$ & 266 & $407-449$ & 433 \\
\hline Dissolved oxygen $\left(\mathrm{mgO}_{2} / \mathrm{L}\right)$ & $11.6-13.5$ & 12.4 & $10.1-12.2$ & 11.1 \\
\hline Oxygen saturation $(\%)$ & $91.8-107.8$ & 103.3 & $85.2-108.7$ & 100.4 \\
\hline Ammonium $(\mathrm{mgN} / \mathrm{L})$ & $<0.0100-0.0240$ & 0.0136 & $<0.0100-0.0340$ & 0.0209 \\
\hline Nitrates $(\mathrm{mgN} / \mathrm{L})$ & $0.4700-0.8800$ & 0.6214 & $0.4200-1.0800$ & 0.7144 \\
\hline Total nitrogen $(\mathrm{mgN} / \mathrm{L})$ & $0.5300-0.9200$ & 0.6786 & $0.6600-1.1000$ & 0.8178 \\
\hline Orthophosphates $(\mathrm{mgP} / \mathrm{L})$ & $<0.005$ & $<0.005$ & $<0.005$ & $<0.005$ \\
\hline Total phosphorus $(\mathrm{mgP} / \mathrm{L})$ & $<0.025$ & $<0.025$ & $<0.025-0.030$ & $<0.025$ \\
\hline
\end{tabular}

Watercourse of the Kupa River, 1.0 - $2.5 \mathrm{~km}$ downstream from the spring is approximately $30 \mathrm{~m}$ wide and, at the time of our visit, 20 to $70 \mathrm{~cm}$ deep. The riverbed was covered only with bryophytes and macroalgae (Fig. 1). The phytosociological relevé of the Kupa River site is: bryophytes - 2b Cinclidotus aquaticus (Hedw.) Bruch \& Schimp., 2b Rhynchostegium riparioides (Hedw.) Cardot, $2 \mathrm{~m}$ Cinclidotus fontinaloides (Hedw.) P. Beauv., 1 Cinclidotus riparius (Host ex Brid.) Arn., + Cratoneuron filicinum (Hedw.) Spruce, + Palustriella falcata (Brid.) Hedenäs; algae -2m Hydrurus foetidus, 1 Cladophora sp., 1 Vaucheria sp.

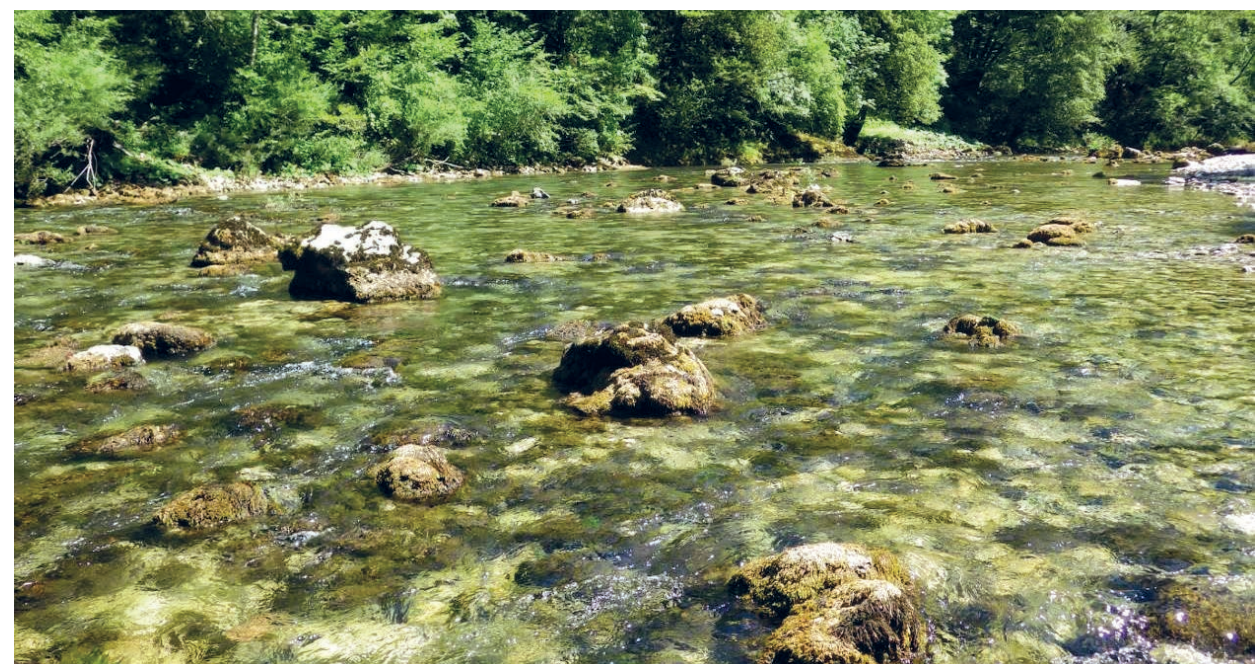

Fig. 1. The habitat of H. foetidus in Kupa River in August 2016 (photo by A. Alegro).

On the second location, the spring area of the Slušnica River, vegetation of vascular plants is richer. The site is located $200 \mathrm{~m}$ downstream from the spring, where the watercourse is approximately $20 \mathrm{~m}$ wide and, at the time of our visit, 30 to $100 \mathrm{~cm}$ deep (Fig. 2). The phytosociological relevé of Slušnica River site is: vascular plants - 2b Berula erecta (Huds.) Coville, 2a Apium repens (Jacq.) Lag., 2a Mentha aquatica L., + Sparganium erectum L.; bryophytes -4 Cratoneuron filicinum, $2 \mathrm{~b}$ Cinclidotus aquaticus (Hedw.) Bruch \& Schimp., 2a Rhynchostegium riparioides, 2a Palustriella falcata; algae -+ Hydrurus foetidus . 


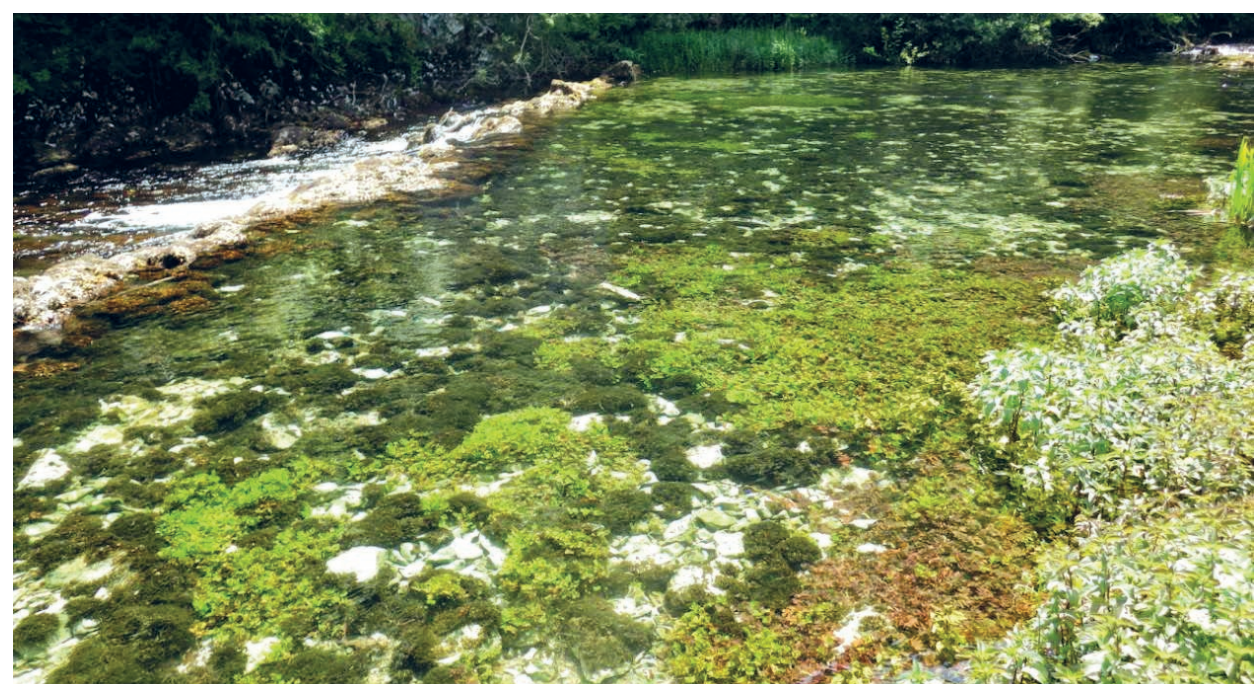

Fig. 2. The habitat of H. foetidus in Slušnica River in July 2017 (photo by A. Alegro).

At both locations, $H$. foetidus was attached to large rocks in a fast running water. During the field research in the Kupa River in August of 2016, the population was abundantly developed with approximately $10 \mathrm{~cm}$ large thalli, but at the disintegration stage. When observed microscopically, the thalli of this population has revealed a parallel pattern of calcium carbonate incrustation, following the direction of the thalli.

The ribbon-like incrustates are located on the surface of the polysaccharide coating and connect several branches of the alga. There were no observed deposits of calcified algae in the riverbed or sediment and we can assume that after the disintegration stage in late summer, this calcified incrustates are washed away by the river flow. During the second research of the Kupa River, in November of 2017, thalli were approximately $5 \mathrm{~cm}$ long and this time at the beginning of its growing stage, with no incrusted parts (Fig. 3). In the Slušnica River the thalli were even larger, approximately $15 \mathrm{~cm}$ long, but the population was scarce. Described vegetation in both rivers, including $H$. foetidus, confirms high water quality according to national methodology for assessment of ecological status (NATional GazeTte, 73/2013, 151/2014, $78 / 2015)$, which is not particularly surprising for the spring areas of mountainous rivers without any anthropogenic influence. Particular emphasis is placed on the recorded Apium repens, a rare helophyte species in Croatia, which was recorded also by the second and the third author on Mrežnica, Tounjčica, Crna rijeka and Dretulja River (unpublished).

The total number of findings of $H$. foetidus, including the previous finding by STANKović \& LeITNER (2016), is presented in Fig. 4. Vegetation monitoring of karst rivers is performed mostly during the summer and does not coincide with the season of intensive growth of $H$. foetidus. Therefore, it is quite possible that many locations have gone unnoticed. Contrary to most other sessile freshwater algae, $H$. foetidus prefers winter conditions in rivers and brooks where temperature is near $0^{\circ} \mathrm{C}$.

In the Kupa River, H. foetidus was found during autumn, which suggests that it may also develop during short-day conditions. The deficit in available light is additionally present due to the location of the area. Namely, it is situated in the canyon, where only diffuse light is available during autumn and winter.

\section{CONCLUSION}

Knowledge about the ecology of the species (Klavenness, 2017; Krizmanić, et al. 2008; Johansson, 1982), general characteristics of karst rivers (BonACCI et al., 2013; CANTONATI et al., 2006; SABATER et al., 1995;) and the large number of karst watercourses in the Dinaric Ecoregion, indicate that these may not be the only localities of this species in Croatia. With the increase of anthropogenic impacts and climatic changes, it is necessary to conduct a more thorough research of the occurrence of freshwater 

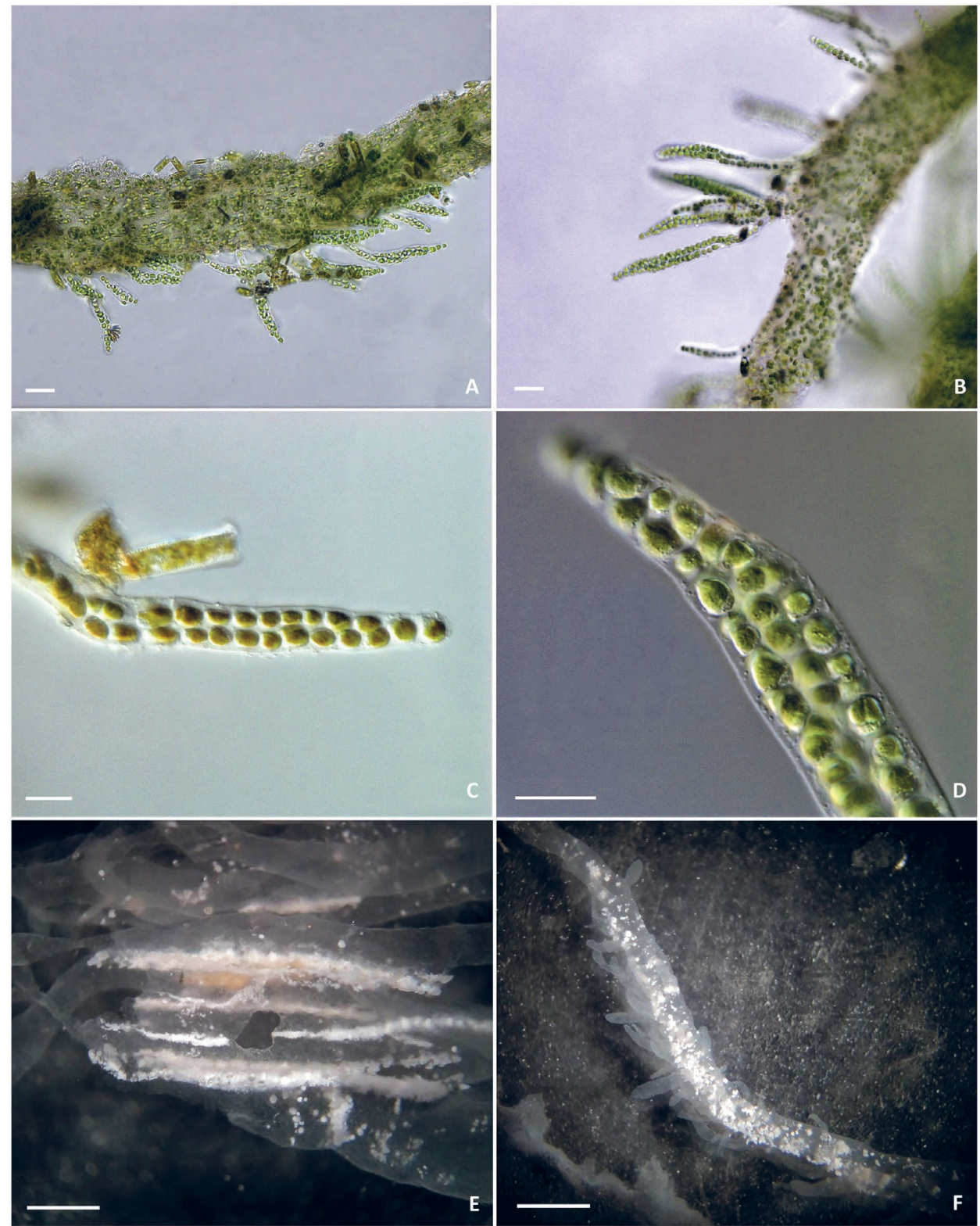

Fig. 3. Thalii of H. foetidus collected in Kupa River in November 2017 (A - D; live material) in its growing stage and in August 2016 (E,F: fixed material) with calcium carbonate incrustation in its disintegra-

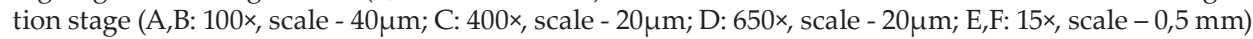
(photo by N. Koletić). 


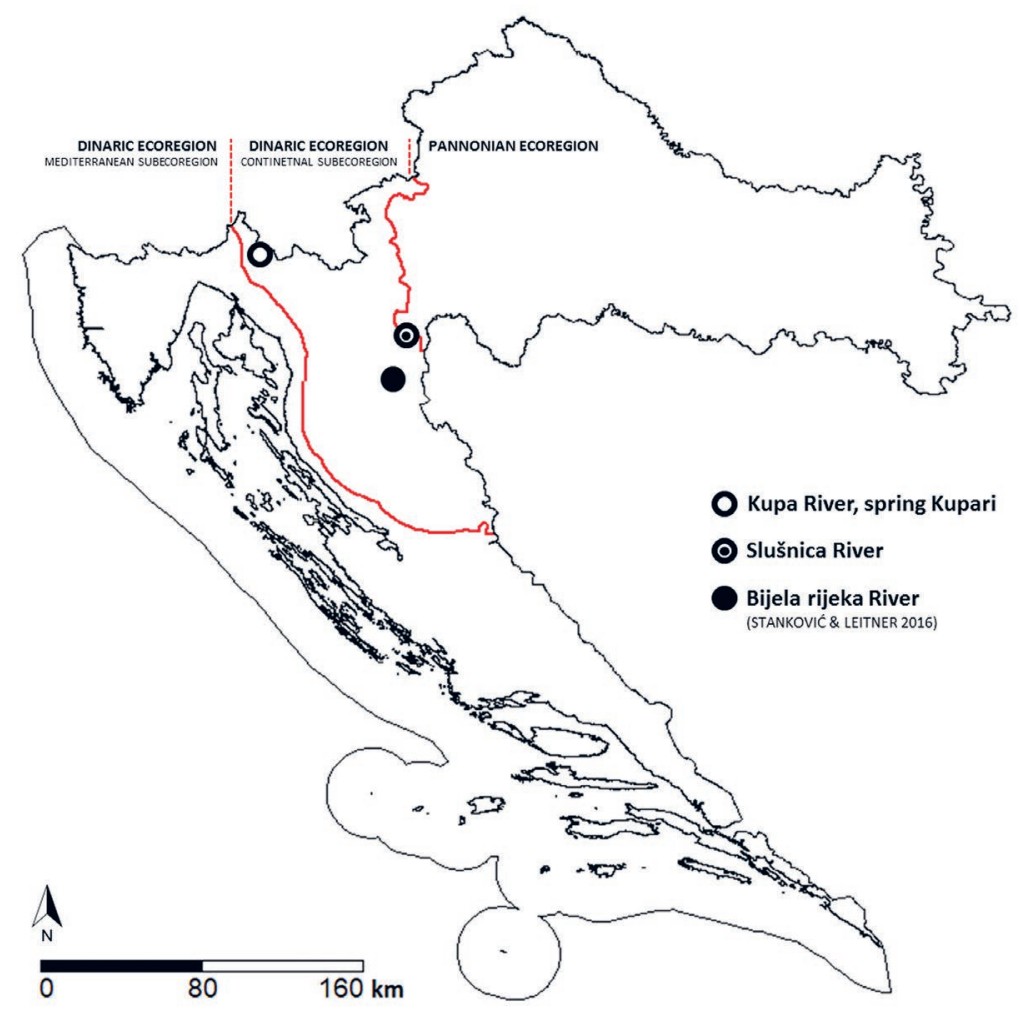

Fig. 4. Locations of $H$. foetidus in Croatia.

benthic macroalgae, which not only indicate high water quality, but also the stability of the aquatic ecosystems. We emphasize the importance of further exploration of mountainous rivers, which can provide information on new locations of $H$. foetidus, and other benthic macroalgae, which obviously represent a vulnerable species in an already vulnerable and unexplored group of organisms in Croatian phycology. In conclusion, it is important to conduct comprehensive phycological studies of mountain streams, especially at the same locations during different seasons.

\section{ACKNOWLEDGEMENTS}

The study was undertaken within the Project of Water Bodies Surveillance, financed by the State Institution for Water Management "Hrvatske vode". We are grateful to the same institution for providing us with the data about physical and chemical properties of water and use of the microscope for photodocumentation purposes. We also warmly thank the staff of the National Park Risnjak for help in organizing and field work management at the Kupa River.

Received September 22, 2017

\section{REFERENCES}

Barkman, J. J., Doing, H. \& Segal, S., 1964: Kritische Bemerkungen und Vorschläge zur quantitativen Vegetationsanalyse. Acta Botanica Neerlandica 13, 394-419.

Bonacci, O., ŽeljKović, I. \& Galić, A., 2013: Karst rivers' particularity: an example from Dinaric karst (Croatia/Bosnia and Herzegovina). Environ Earth Sci 70, 963-974. 
Braun-Blanquet, J., 1964: Pflanzensoziologie. Grundzüge der Vegetationskunde. 3. Aufl. Springer Verl., Wien, New York.

Bursa, A., 1934: Hydrurus foetidus Kirch. w Polskich Tatrach. - Hydrurus foetidus Kirch. in der Polnischen Tatra. I. Oekologie, Morphologie. II. Phenologie. Bull Int l'Académie Polonaise des Sciences des Lettres (Classe des Sciences Mathématiques Naturelles. Série B: Sciences Naturelles (I)) 69-84 + 113-31.

Cantonati, M., Gerecke, R. \& Bertuzzi, E., 2006: Springs of the Alps - sensitive ecosystems to environmental change: from biodiversity assessments to long-term studies. Hydrobiologia 562, 59-96.

Dierschke, H., 1994: Pflanzensoziologie. Grundlagen und Methoden. Eugen Ulmer Verl., Stuttgart.

EURO+MED, 2017: Euro+Med PlantBase - the information resource for Euro-Mediterranean plant diversity. Retrieved May 16, 2017 from http://ww2.bgbm.org/EuroPlusMed/.

Guiry. M. D. In: Guiry, M. D. \& Guiry, G. M., 2017, AlgaeBase. World-wide electronic publication, National University of Ireland, Galway. http://www.algaebase.org; searched on 07 September 2017.

Hrvatska Agencija Za Oкоliš I Prirodu, 2015: Bioportal (available at http://www.bioportal.hr/gis/).

Hrvatske Vode, 2015: Nacrt Plana upravljanja vodnim područjima 2016. - 2021. (Draft River Basin Management Plan 2016. - 2021.), Hrvatske vode, Zagreb, Hrvatska.

Johansson, C., 1982: The ecological characteristics of 314 taxa found in Jämtland streams, Sweden. Meddelan från Växtbiologiska institusjonen, Uppsala, 1882(2), 1-170.

KANN, E., 1978: Systematik und Ökologie der Algen österreichischer Bergbäche. Arch Hydrobiol/Suppl 53(4), 405-643.

Kawecka, B., 1981: Sessile algae in European mountain streams 2. Taxonomy and autecology. Acta Hydrobiol. 23, 17-46.

KaweckA, B., 2003: Effect of different light conditions on cyanobacteria and algal communities in Tatra Mts stream (Poland). Ocean. Hydrobiol. Stud. 32(2), 3-13.

KLAveness, D., 2017: Hydrurus foetidus (Chrysophyceae) - an inland macroalga with potential. Journal of Applied Phycology 29, 1485-1491.

KLaveness, D. \& Lindstrøm, E.-A., 2011: Hydrurus foetidus (Chromista, Chrysophyceae): A large freshwater chromophyte alga in laboratory culture. Phycological Research 59, 105-112.

Krizmanić, J., Subakov-Simić, G. \& Karadžıć, V., 2008: Supplementary notes on the distribution of Hydrurus foetidus (Vill.) Trevisan (Chrysophyta) in Serbia. Arch. Biol. Sci., Belgrade 60(2), 13-14.

National Gazette 73/2013, 151/2014, 78/2015 Uredba o standardu kakvoće voda (Regulation on the Water Quality Standard).

National Gazette 124/2013, 105/2015 Uredba o ekološkoj mreži (Regulation on the ecological network).

Rott, E., Füreder, L., Schütz, C., Sonntag, B. \& Wille, A., 2006a: A conceptual model for niche differentiation of biota within an extreme stream microhabitat. Int Ver Theor Angew Limnol, Verh 29, 23212323.

Rott, E., Cantonati, M., Füreder, L. \& Pfister, P., 2006b: Benthic algae in high altitude streams of the Alps - a neglected component of the aquatic biota. Hydrobiologia 562, 195-216.

Sabater, F., Guasch, H., Marti, E., Armengol, J. \& Sabater, S., 1995: The Ter: a Mediterranean river casestudy in Spain. In: Cushing, C. E., Cummins, K. W. \& Minshall, G. W. (eds.), River and stream Ecosystems. Ecosystems of the World 22, 419-438.

Stanković, I. \& Leitner, P., 2016: The first record of Hydrurus foetidus (Villars) Trevisan (Ochrophyta: Chrysophyceae) in Croatia with ecological notes. Nat. Croat. 25(2), 223 -231.

Starmach, K., 1985: Süßwasserflora von Mitteleuropa, Bd. 1. Chrysophyceae und Haptophyceae, Gustav Fischer Verlag, Stuttgart.

Souires, L. E., Rushforth, S. R. \& Endsley, C. J., 1973: An ecological survey of the algae of Huntington Canyon, Utah. Brigham Young Univ. Sci. Bull., Biol. Ser. 18(2), 1-87.

Thiers, B., 2016: Index Herbariorum: A global directory of public herbaria and associated staff. New York Botanical Garden's Virtual Herbarium. Retrieved May 16, 2017 from: http://sweetgum.nybg.org/ih/.

WARD, J. V., 1994: Ecology of alpine streams. Freshw. Biol. 32, 277-94.

Wehr, J. D. \& Sheath, R. G., 2003: Freshwater Habitats Of Algae. In: Wehr, J. D. \& Sheath, R. G. (eds.), Freshwater Algae of North America - Ecology and Classification. Academic Press, San Diego/Burlington, p. 11-57.

Wehr, J. D., Sheath, R. G. \& Kociolek, R. P., 2015: Freshwater Algae of North America: Ecology and Classification, Second edn, Academic Press, Amsterdam. 